Supplement of

\title{
Long-term observations of cloud condensation nuclei over the Amazon rain forest - Part 2: Variability and characteristics of biomass burning, long-range transport, and pristine rain forest aerosols
}

Mira L. Pöhlker et al.

Correspondence to: Mira L. Pöhlker (m.pohlker@mpic.de) and Christopher Pöhlker (c.pohlker@mpic.de)

The copyright of individual parts of the supplement might differ from the CC BY 4.0 License. 


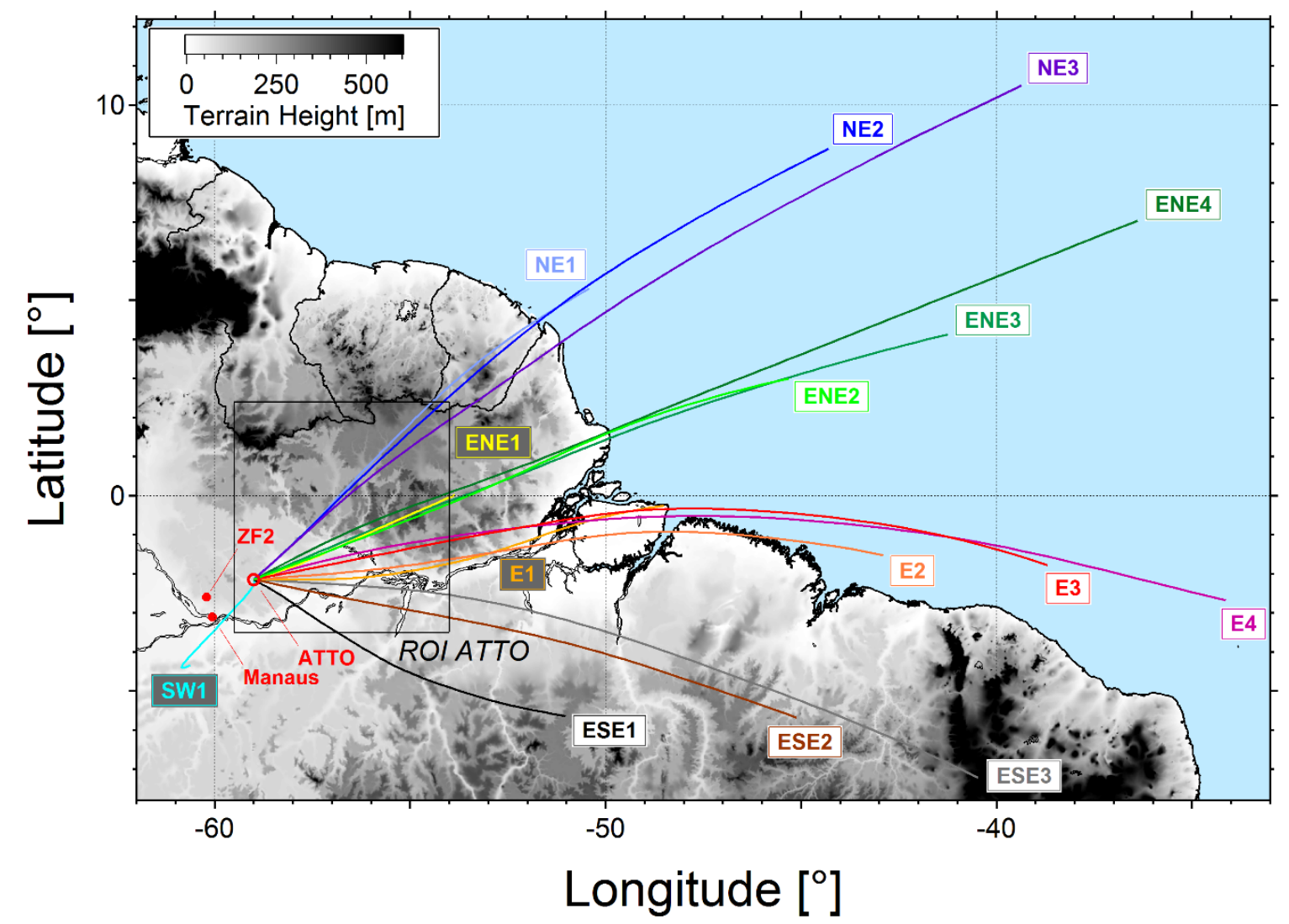

Figure S1. Map of northeast Amazon Basin with 15 clusters from $k$-means backward trajectory cluster analysis based on multiyear HYSPLIT data set (3-day BTs, 1 Jan 2008 - 30 Jun 2016, start height $1000 \mathrm{~m}$ AGL). Backward trajectory clusters show that air masses arrive at the ATTO site almost exclusively from northeastern to southeastern directions. Four major wind directions can be discriminated: (i) Northeastern (NE) clusters NE1, NE2, and NE3; (ii) east-northeastern (ENE) clusters ENE1, ENE2, ENE3, and ENE4; (iii) eastern (E) clusters E1, E2, E3, and E4; (iv) east-southeastern (ESE) clusters ESE1, ESE2, and ESE3. In addition, a separate cluster is directed towards the southwest (SW). A topographic map is represented by a grey scale, which is capped at $600 \mathrm{~m}$. Highlighted area represents region of interest $\mathrm{ROI}_{\text {AтTO }}\left(59.5^{\circ} \mathrm{W}\right.$ to $54^{\circ} \mathrm{W}$ and $3.5^{\circ} \mathrm{S}$ to $\left.2.4^{\circ} \mathrm{N}\right)$. The figure has been adapted from C. Pöhlker et al. (2018), where a detailed description of the BT analysis can be found. 


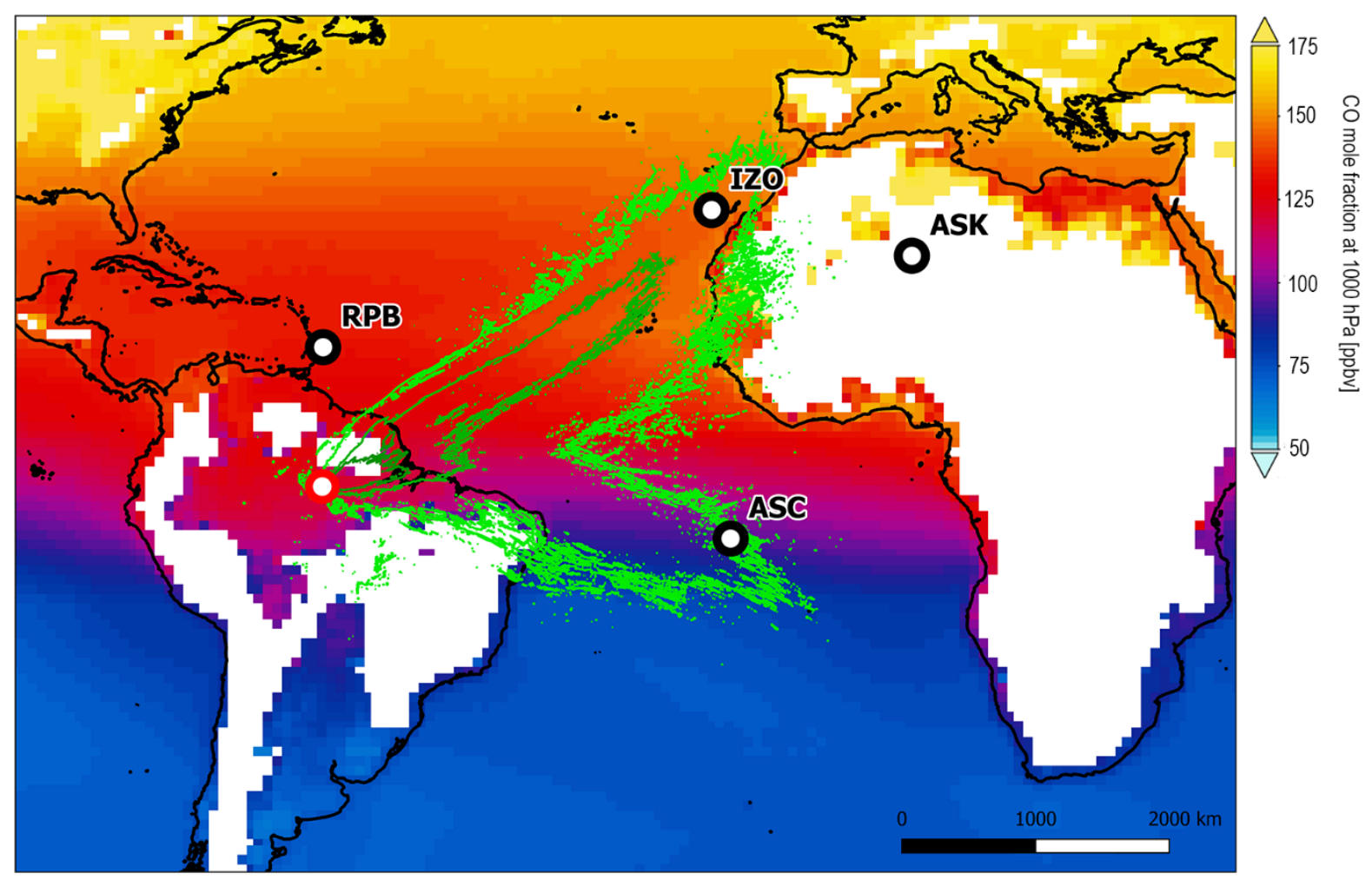

Figure S2. Satellite-derived map of CO mole fraction at ground level $(1000 \mathrm{hPa}$, from AIRS instruments on board of the satellites Terra and Aqua) representing the average of the wet season periods (Feb to May) from 2012 to 2016. Green contour lines represent ATTO backward trajectory (BT) ensemble during wet season conditions (Feb to May) for years 2012 to 2016. Contour lines show upper $0.5 \%$, upper $5 \%$, and upper $25 \%$ of BT-derived air mass residence times (for details see C. Pöhlker et al., 2018). Also shown are four background stations with monthly CO monitoring: Ragged Point, Barbados (RPB), Izaña, Tenerife, Canary Island (IZO), and Assekrem, Algeria (ASK) representing the northern hemispheric CO background vs. Ascension Island (ACS) representing southern hemispheric $\mathrm{CO}$ background. Data from CO background station was used in the definition of $P R_{\mathrm{CO}}$ filter for ATTO data (Sect. 2.7). 
(a) Northeasterly (NE) backward trajectory clusters

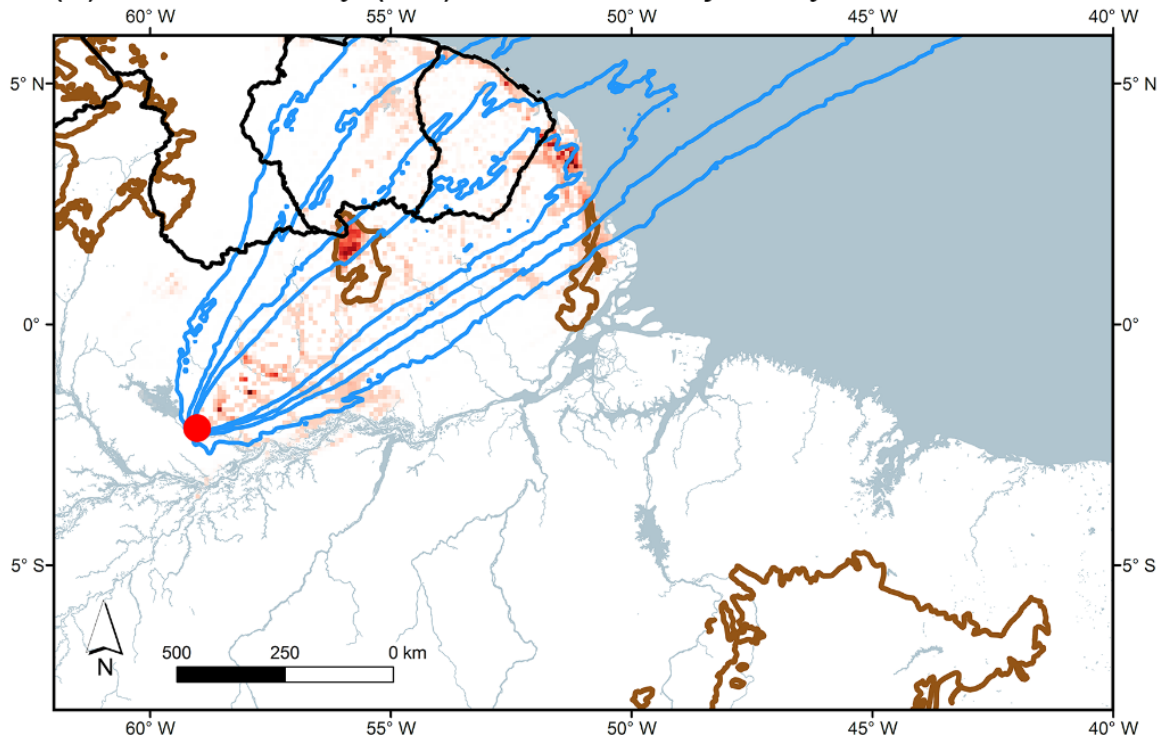

(b) East-northeasterly (ENE) backward trajectory clusters

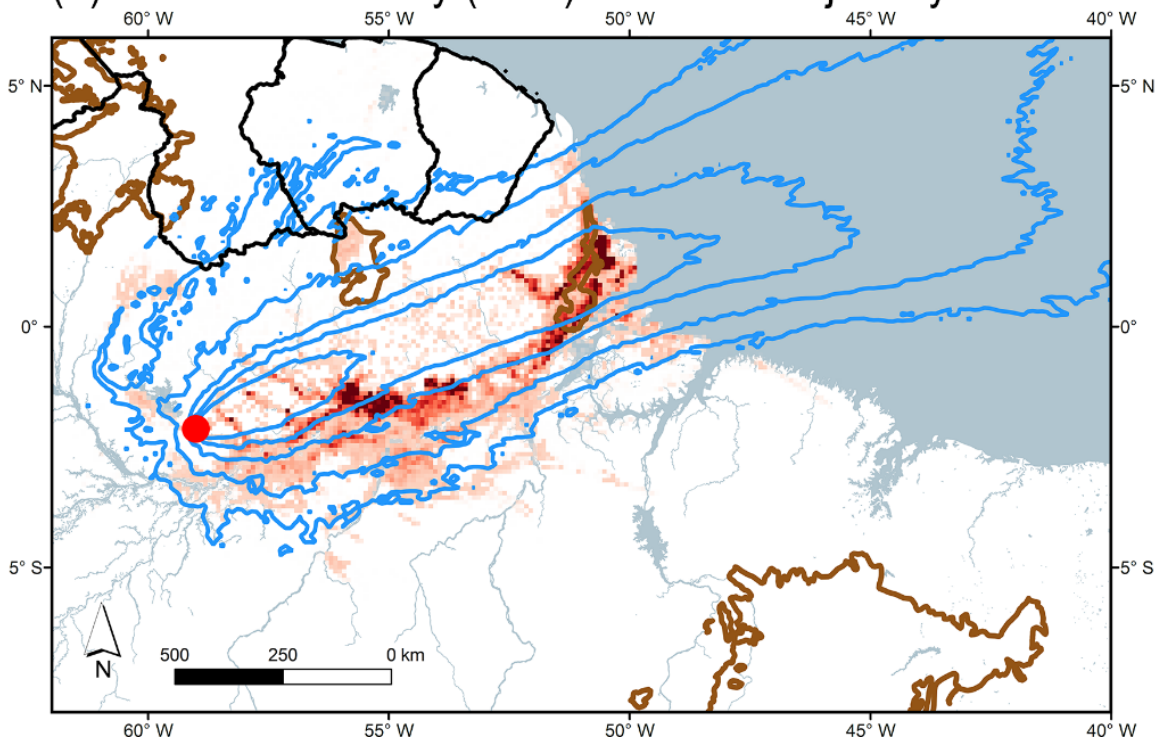

Counted fires, weighted by BT-related air mass residence times

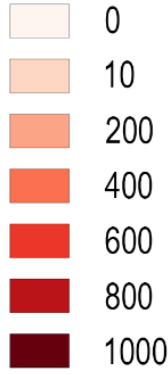

Margins of savanna ecoregions

Contour lines representing upper $1 \%$, $5 \%, 10 \%, 25 \%$, and $50 \%$ of air mass residence times

Figure S3. Fire maps being weighted with backward trajectory-derived air mass residence times for northeasterly BT clusters (i.e., NE1, NE2, NE3) and east-northeasterly BT clusters (ENE1, ENE2, ENE3, ENE4) according to C. Pöhlker et al. (2018). BT ensembles are shown as contour lines representing upper $1 \%, 5 \%, 10 \%, 25 \%$, and $50 \%$ of air mass residence times. Fire maps were created as outlined in C. Pöhlker et al. (2018). Geographic extent of savanna ecoregions has been obtained from Olson et al. (2001). Maps show that fire activity in footprint region of NE BT is overall rather low, with few fires in rain forest areas. However, relatively high fire abundance occurs in Guianan savanna region that is located in center of NE BT ensemble. This savanna region is still rather unperturbed by human activities and, thus, observed fires are likely predominantly wild fires according to de Carvalho and Mustin (2017). Fire activity in footprint of ENE BTs is mostly located along Amazon River valley, which is strongly influenced by human activities. Accordingly, these fire appear to be mostly man made. 


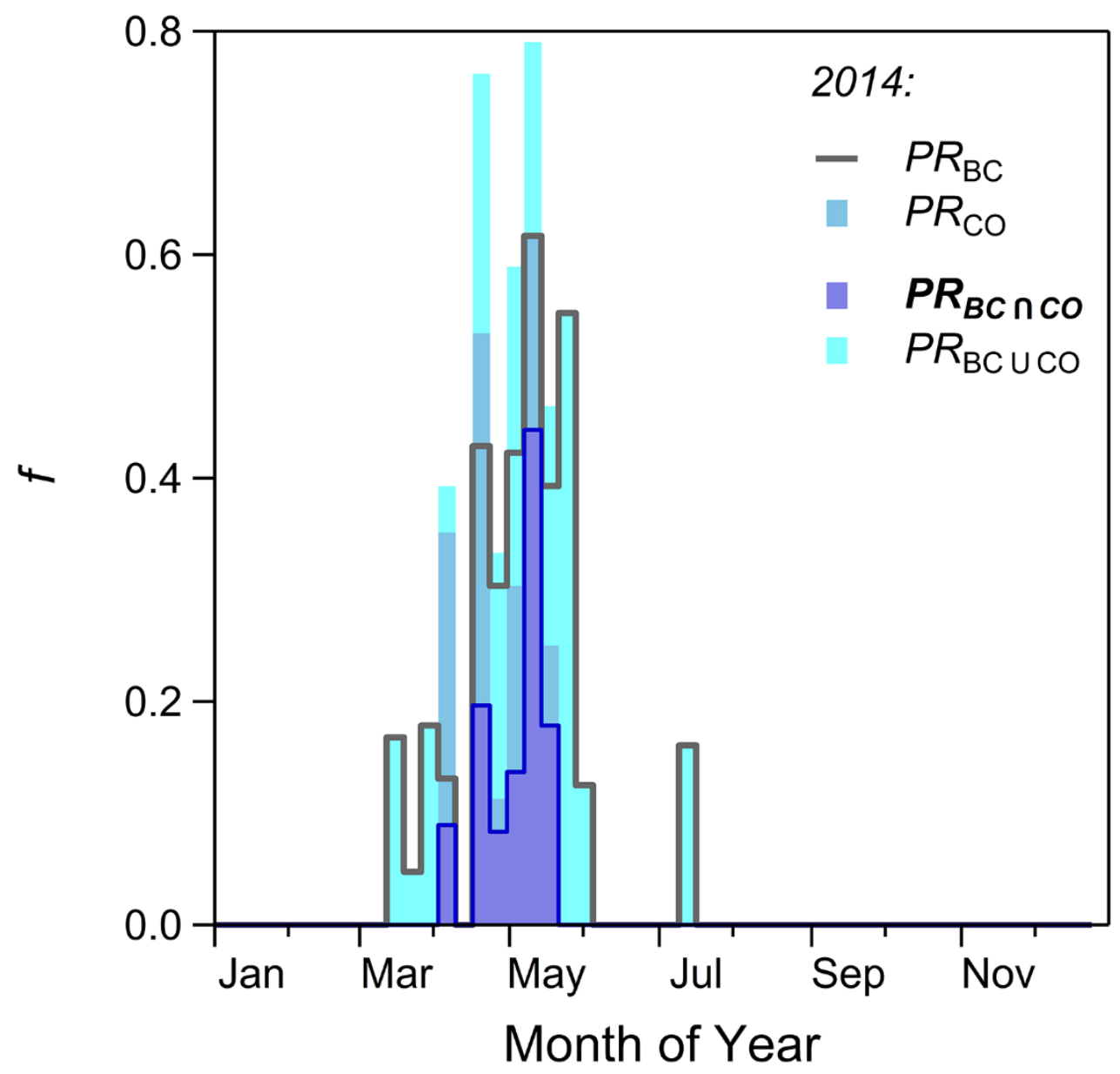

Figure S4. Seasonality of frequency of occurrence, $f$, of empirically pristine rain forest $(P R)$ aerosol conditions at ATTO by means of $P R_{B C}, P R_{C O}, P R_{B C} \cap C O$, and $P R_{B C} \cup C O$ filters (see Sect. 2.7). $P R_{B C} \cap C O$ as most robust case is used as main $P R$ filter throughout this work. Data is shown as weekly averages for year 2014, covering most of the CCN focal period of this study. For analogous representation of multi-year period, refer to Fig. 1. 


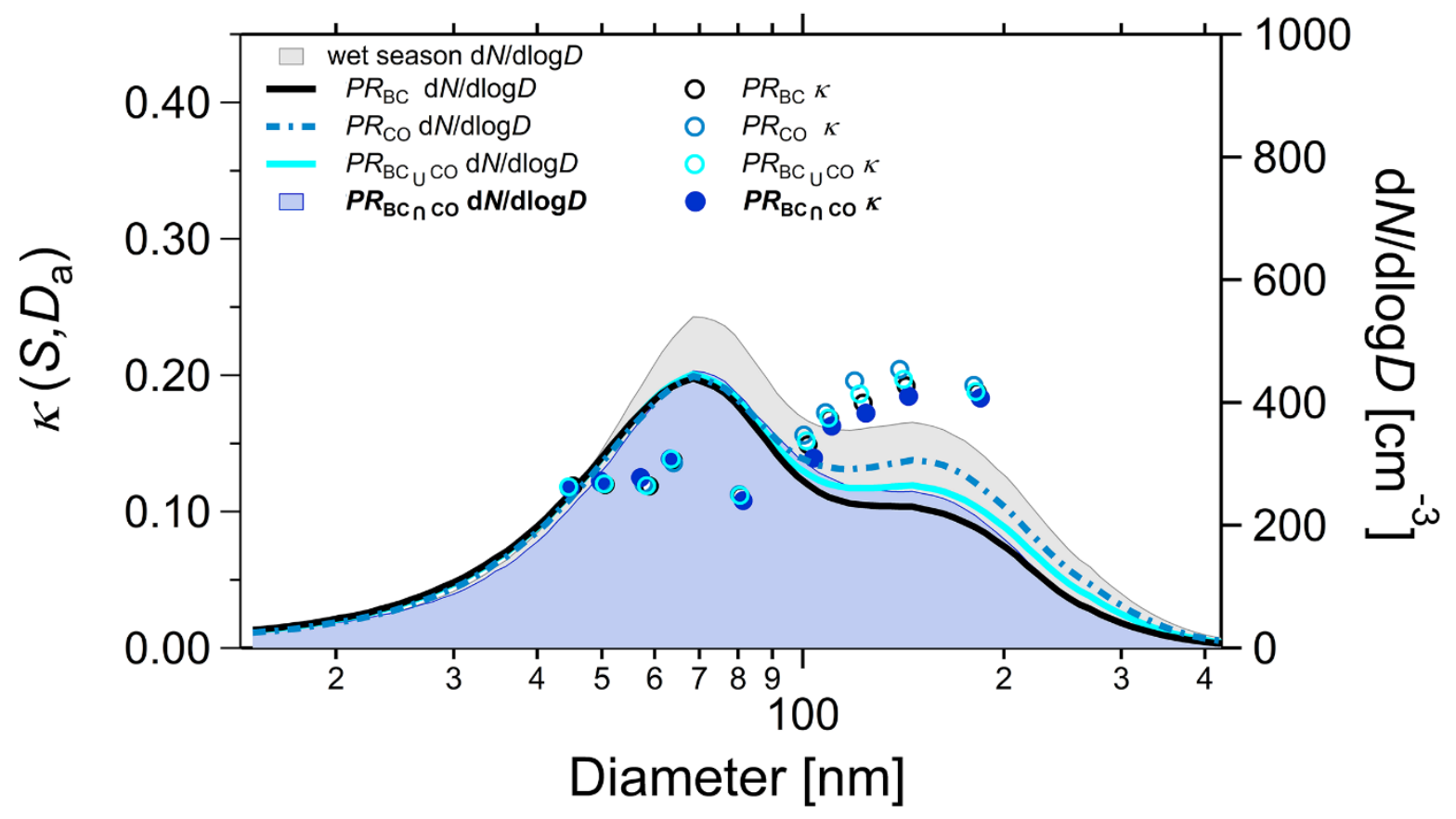

Figure S5. Size dependence of hygroscopicity parameter, $\kappa\left(S, D_{\mathrm{a}}\right)$, and number size distributions of total aerosol particles, $N_{\mathrm{CN}}(D)$, for all four $P R$ filters (i.e., $P R_{B C}, P R_{C O}, P R_{B C} \cap C O, P R_{B C} \cup C O$, see Sect. 2.7). Values of $\kappa\left(S, D_{\mathrm{a}}\right)$ for every $S$ level are plotted against their corresponding midpoint activation diameter, $D_{\mathrm{a}}(S)$. The average wet season $N_{\mathrm{CN}}(D)$ size distributions (in grey) from the part 1 study (M. Pöhlker et al., 2016) has been added. The comparison shows that the $P R$ filters give rather similar results, particularly in the Aitken mode size range. Certain, although minor, differences can be seen in the accumulation mode size range. 
(a) Statistically filtered size distributions - wet season

-23 March - 31 May 2014: $N_{\text {ait }} \sim 154 \quad N_{\text {acc }} \sim 162 \mathrm{~cm}^{-3}$

- . . . - 90\% percentile from $N_{\mathrm{CN}_{1} 10}: N_{\text {ait }} \sim 139 N_{\text {acc }} \sim 147 \mathrm{~cm}^{-3}$

— $65 \%$ percentile from $N_{\mathrm{CN}, 10}: N_{\text {ait }} \sim 118 \quad N_{\text {acc }} \sim 115 \mathrm{~cm}^{-3}$

- a = = 50\% percentile from $N_{\mathrm{CN}, 10}: N_{\text {ait }} \sim 105 N_{\mathrm{acc}} \sim 102 \mathrm{~cm}^{-3}$

$35 \%$ percentile from $N_{\mathrm{CN}, 10}: N_{\text {ait }} \sim 98 \quad N_{\text {acc }} \sim 82 \mathrm{~cm}^{-3}$

-...- $10 \%$ percentile from $N_{\mathrm{CN}, 10}: N_{\text {ait }} \sim 86 \quad N_{\text {acc }} \sim 41 \mathrm{~cm}^{-3}$

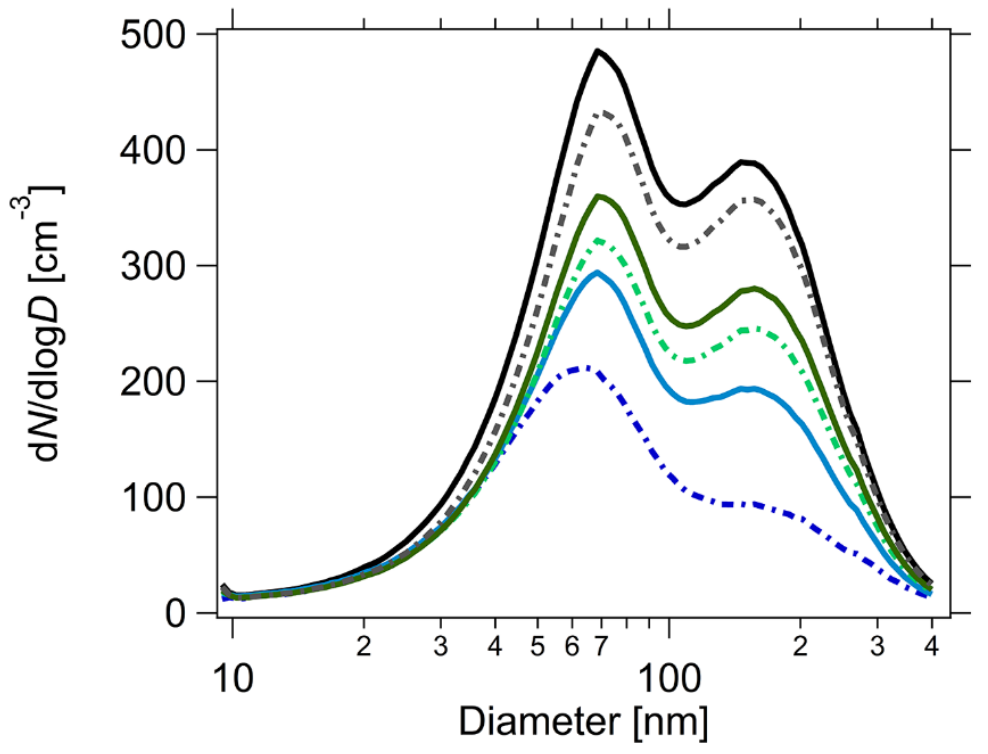

(b) Statistically filtered size distributions - PR

PR: $N_{\text {ait }} \sim 162 \quad N_{\text {acc }} \sim 86 \mathrm{~cm}^{-3}$

- : = = 90\% percentile from $N_{\mathrm{CN}, 10}$ of $P R: N_{\text {ait }} \sim 144$

- $65 \%$ percentile from $N_{\mathrm{CN}, 10}$ of $P R: N_{\text {ait }} \sim 111$

$=-=50 \%$ percentile from $N_{\mathrm{CN}, 10}$ of $P R: N_{\text {ait }} \sim 99$

$35 \%$ percentile from $N_{\mathrm{CN}, 10}$ of $P R: N_{\text {ait }} \sim 87$

- . - - $10 \%$ percentile from $N_{\mathrm{CN}, 10}$ of $P R: N_{\text {ait }} \sim 69$

$N_{\text {acc }} \sim 76 \mathrm{~cm}^{-3}$

$N_{\text {acc }} \sim 63 \mathrm{~cm}^{-3}$

$N_{\text {acc }} \sim 53 \mathrm{~cm}^{-3}$

$N_{\text {acc }} \sim 41 \mathrm{~cm}^{-3}$

$N_{\text {acc }} \sim 24 \mathrm{~cm}^{-3}$

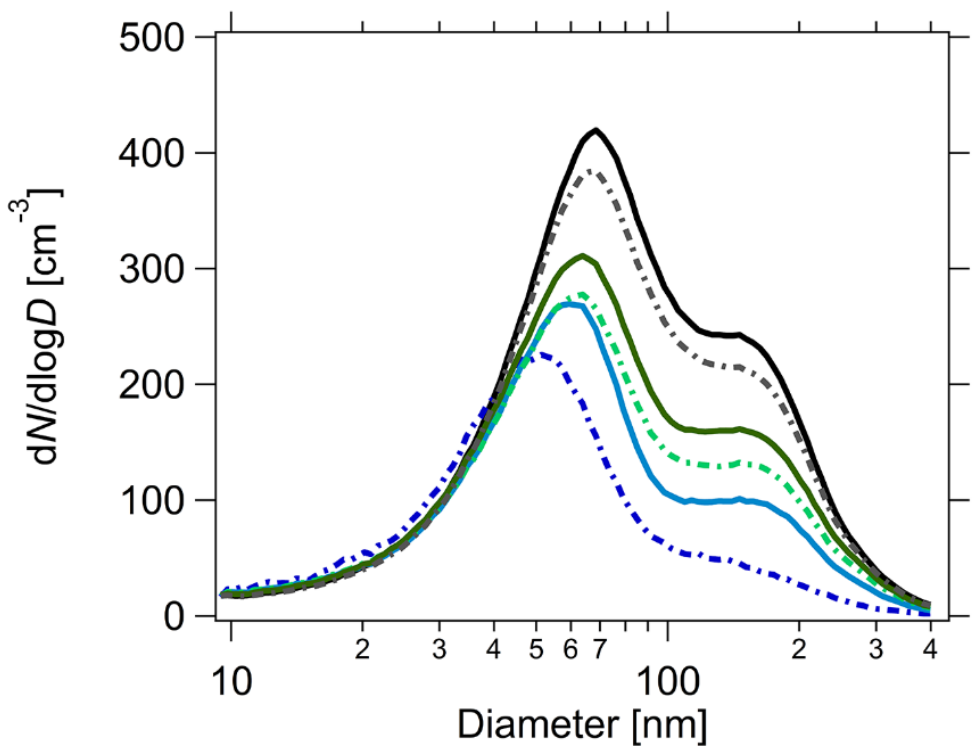

Figure S6. Number size distributions of total aerosol particles, $N_{\mathrm{CN}}(D)$, classified by means of a statistical analysis of the total aerosol number concentration. Characteristic spectra for defined percentiles are shown for wet season vs. $P R$ conditions. The comparison shows that the characteristic bimodal size distribution (i.e., relative strength of Aitken and accumulation modes) under wet season and $P R$ conditions are rather stable. The distributions for the $10 \%$ percentile of $N_{\mathrm{CN}, 10}$ deviate most clearly due to rain-related scavenging, which decreases the accumulation more strongly than the Aitken mode through activation of accumulation mode particles as CCN (compare Sect. 3.4). 


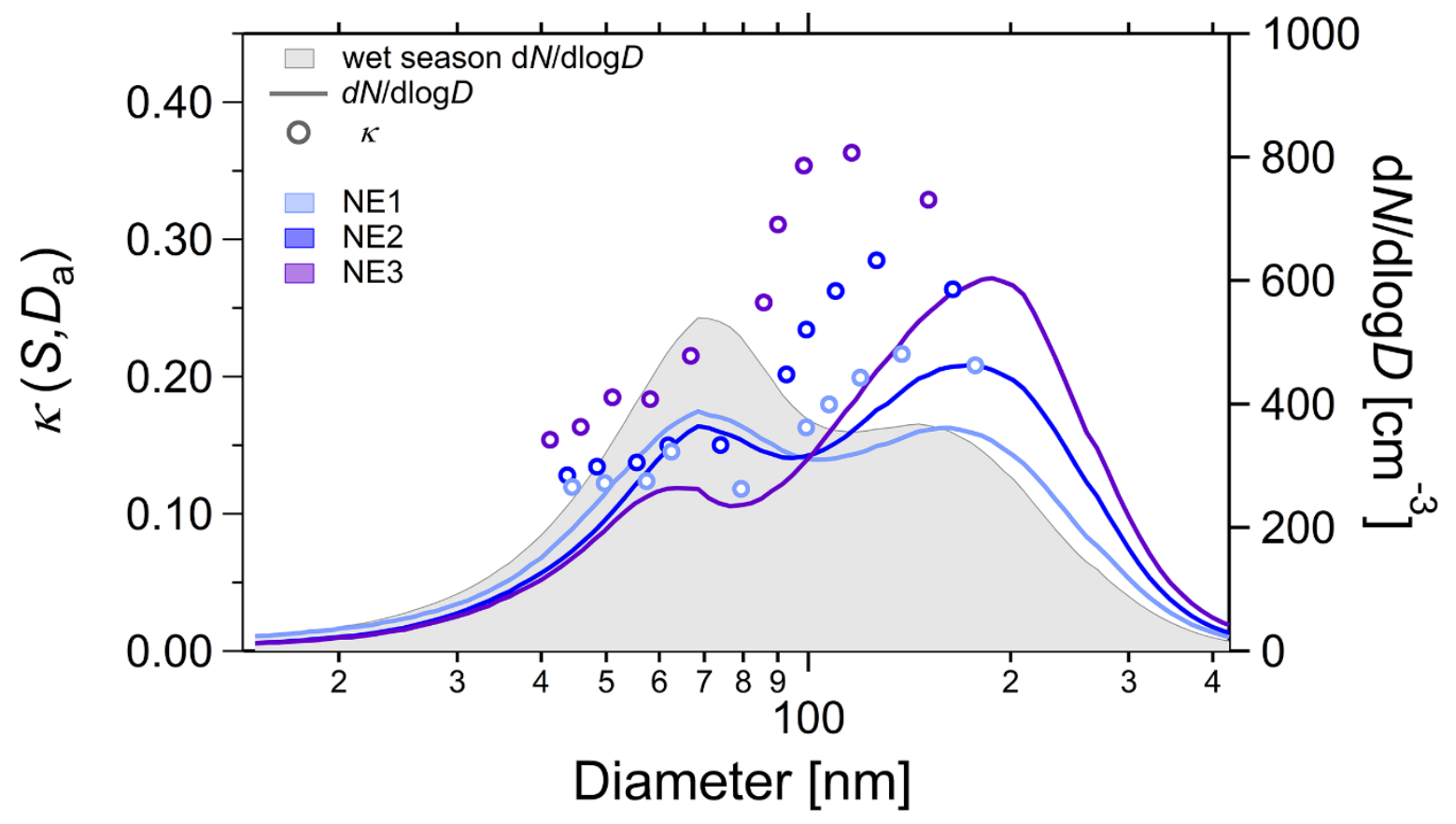

Figure S7. Size dependence of hygroscopicity parameter, $\kappa\left(S, D_{\mathrm{a}}\right)$, and number size distributions of total aerosol particles, $N_{\mathrm{CN}}(D)$, for northeasterly (NE) backward trajectory (BT) clusters according to C. Pöhlker et al. (2018). Values of $\kappa\left(S, D_{\mathrm{a}}\right)$ for every $S$ level are plotted against their corresponding midpoint activation diameter, $D_{\mathrm{a}}(S)$. The average wet season spectrum from the companion part 1 study (M. Pöhlker et al., 2016) has been added for comparison. The figure shows rather pronounced differences between the three NE clusters due to the fact that the NE3 BTs are most efficient in transporting African LRT plumes into the Amazon Basin during its wet season (compare MoranZuloaga et al., 2017). The NE1 BTs are least efficient in LRT transport due to strong rain-related scavenging. The NE2 BTs represent an intermediate case. Accordingly the $N_{\mathrm{CN}}(D)$ and $\kappa\left(S, D_{\mathrm{a}}\right)$ size distributions for NE3 resemble the LRT results in Fig. 6c, the NE1 case is most similar to the $P R$ results in Fig. 6a, whereas the NE2 case resembles a mixture of both. 


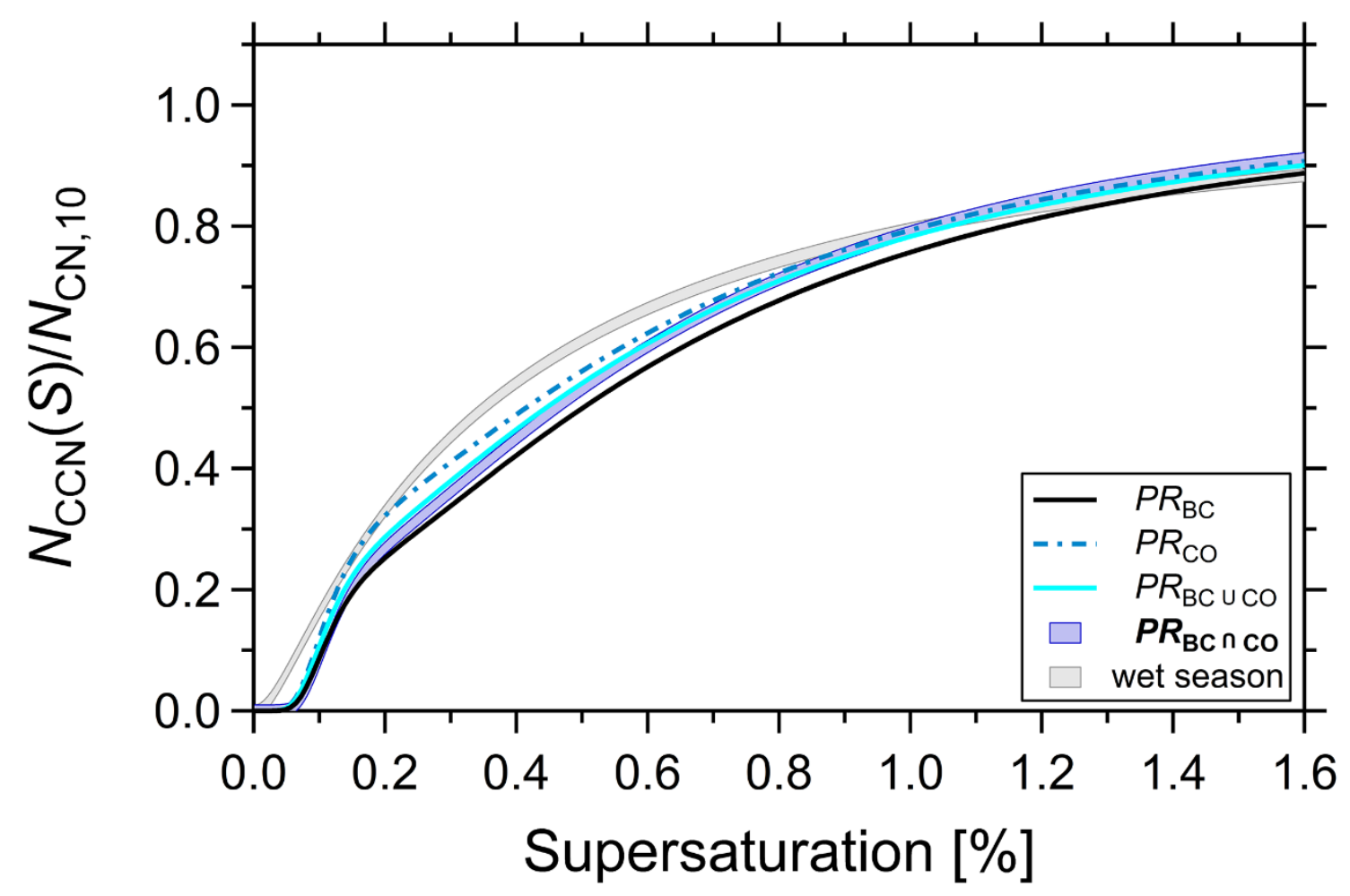

Figure S8. Erf fits of $\mathrm{CCN}$ efficiency spectra for all $P R$ filters (i.e., $P R_{B C}, P R_{C O}, P R_{B C} \cap C O, P R_{B C} \cup C O$, see Sect. 2.7). The average $C C N$ efficiency spectrum for wet season conditions from companion part 1 study (M. Pöhlker et al., 2016) has been added for comparison. The figure shows that the $P R$ filters give rather similar CCN efficiency spectra. Minor differences in accumulation mode strength as shown in Fig. S5 result here in slightly different shapes of $P R$ CCN efficiency spectra. 
(a) Wet season, $P R \& L R T$

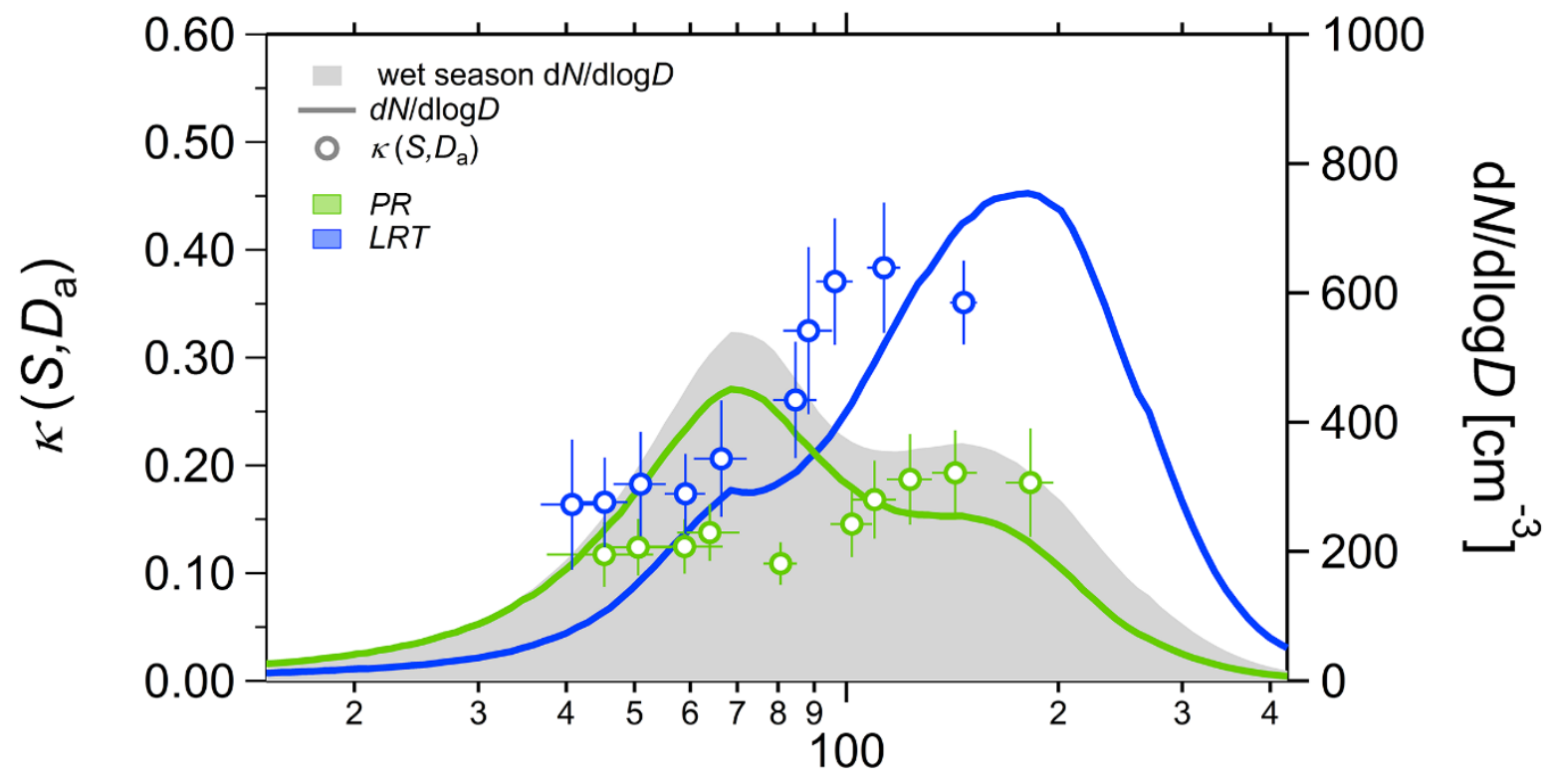

Diameter [nm]

(b) Dry season, $B B \& M P O L$

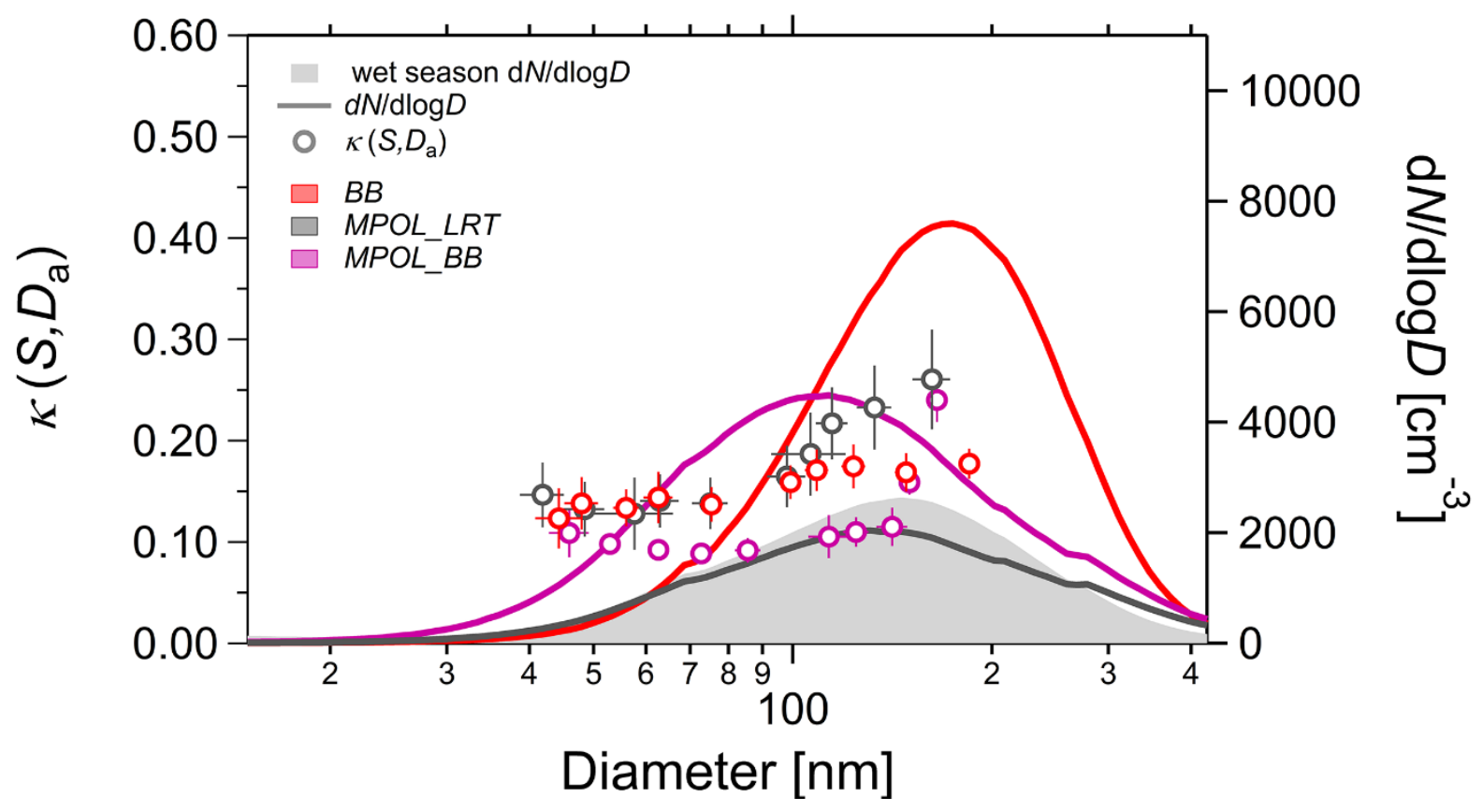

Figure S9. Overview figure combining $N_{\mathrm{CN}}(D)$ and $\kappa\left(S, D_{\mathrm{a}}\right)$ size distributions for $P R, L R T, B B, M P O L$ $L R T$, and $M P O L-B B$ conditions as well as average wet and dry season results from companion part 1 paper (M. Pöhlker et al., 2016). Values of $\kappa\left(S, D_{\mathrm{a}}\right)$ for every $S$ level are plotted against their corresponding midpoint activation diameter $D_{\mathrm{a}}(S)$. For $\kappa\left(S, D_{\mathrm{a}}\right)$, the error bars represent one std. For $D_{\mathrm{a}}(S)$, the experimentally derived error is shown. 

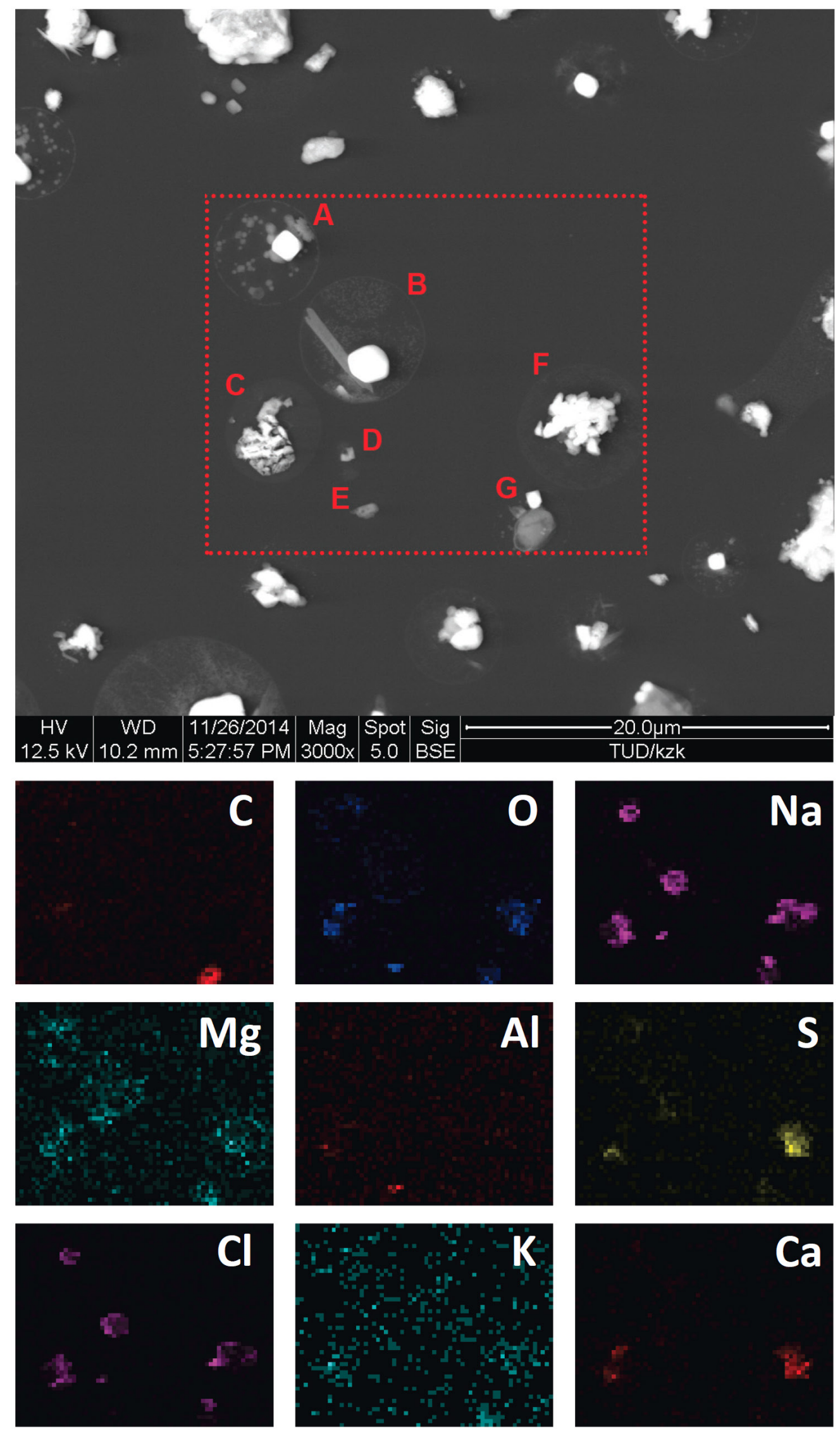

Figure S10. SEM images and EDX maps for selected aerosol sample showing typical appearance of LRT aerosol population at ATTO. Sample shows processed and internally mixed sea spray and dust particles. The results are based on an aerosol sample, collected on $15^{\text {th }}$ Feb 2014 during LRT event 2014_2 according to Moran-Zuloaga et al. (2017), which is comparable (i.e., transport patterns, 
physicochemical properties recorded by online measurements) to the event discussed as LRT case study in the present work. The particles A, B, and D resemble sea spray particles with a (large) cubic crystal of $\mathrm{NaCl}$ as well as weaker signals in $\mathrm{Mg}$, $\mathrm{O}$, and $\mathrm{S}$ (likely as $\mathrm{MgSO}_{4}$ ). Morphologically, the particles show similarities to examples of aged sea-salt particles in previous studies (e.g., Laskin et al., 2012). The needle-like structure in particle $\mathrm{B}$ could be a $\mathrm{CaSO}_{4}$ crystal that appears to be too 'thin' to give a clear signal in the EDX maps. The particles $\mathrm{C}$ and $\mathrm{F}$ also show a strong $\mathrm{NaCl}$ signal. In addition, they reveal strong signals in $\mathrm{S}, \mathrm{O}$, and $\mathrm{Ca}$. These particles resemble $\mathrm{CaCO}_{3}$ particles from the Saharan dust plume, in which the $\mathrm{CO}_{3}{ }^{2-}$ anion was (partly) replaced by $\mathrm{SO}_{4}{ }^{2-}$ in the course of atmospheric processing. Similar particles have been described in Laskin et al. (2005). Upon processing, a certain amount of $\mathrm{NaCl}$ appears to be mixed in most particles. Particle $\mathrm{G}$ comprises a $\mathrm{NaCl}$ crystal that is attached to PBAP-like particle (based on morphology and strong $\mathrm{C}$ signal). Particle $\mathrm{E}$ shows signals in $\mathrm{Al}$ and $\mathrm{O}$, which fit to an alumosilicate particle. 

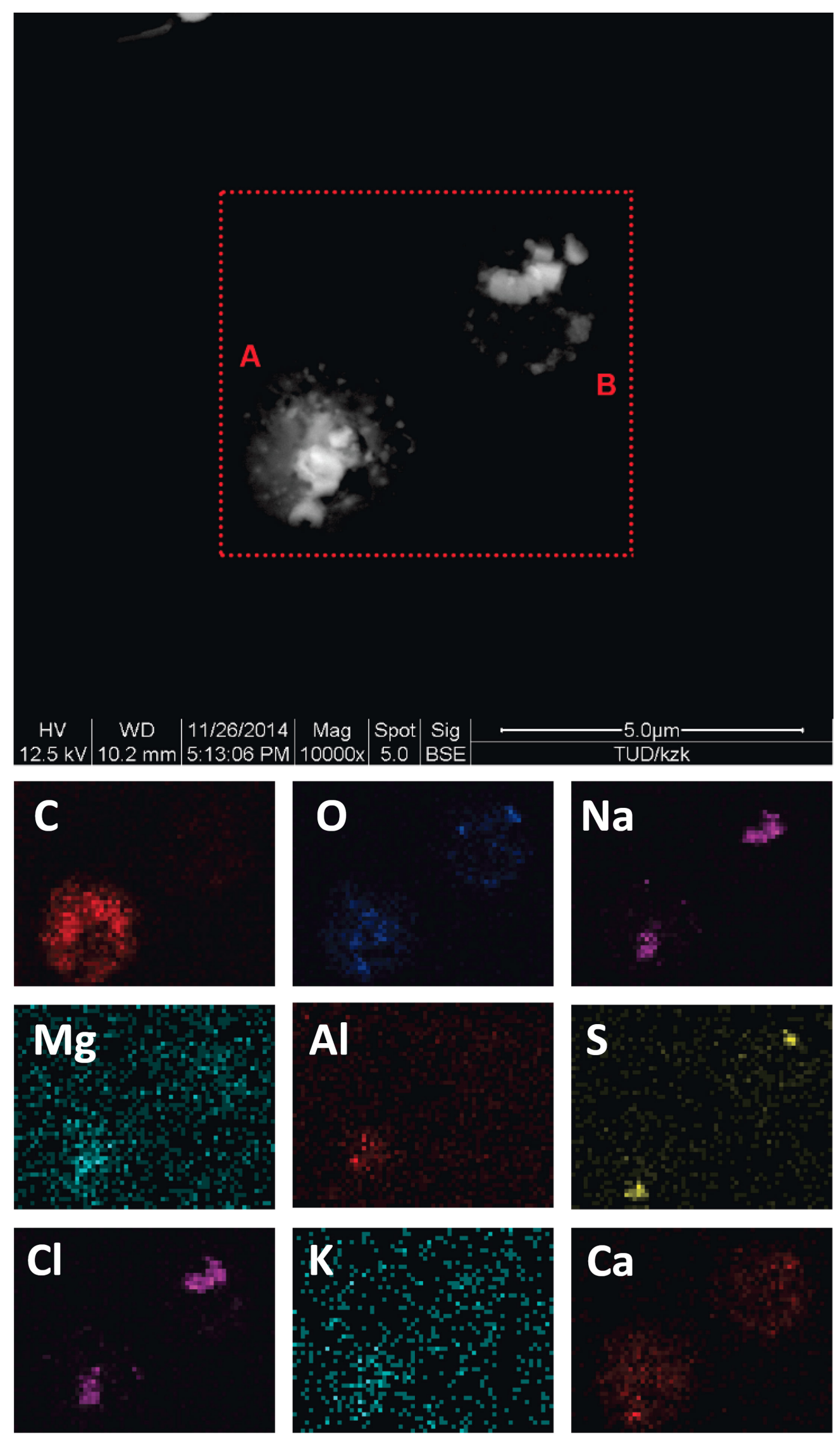

Figure S11. SEM images and EDX maps for selected aerosol sample showing a further example of the typical appearance of LRT aerosol population at the ATTO site. Sample shows processed and internally mixed sea spray and dust particles. For further relevant details, refer to caption on Fig. S10. 


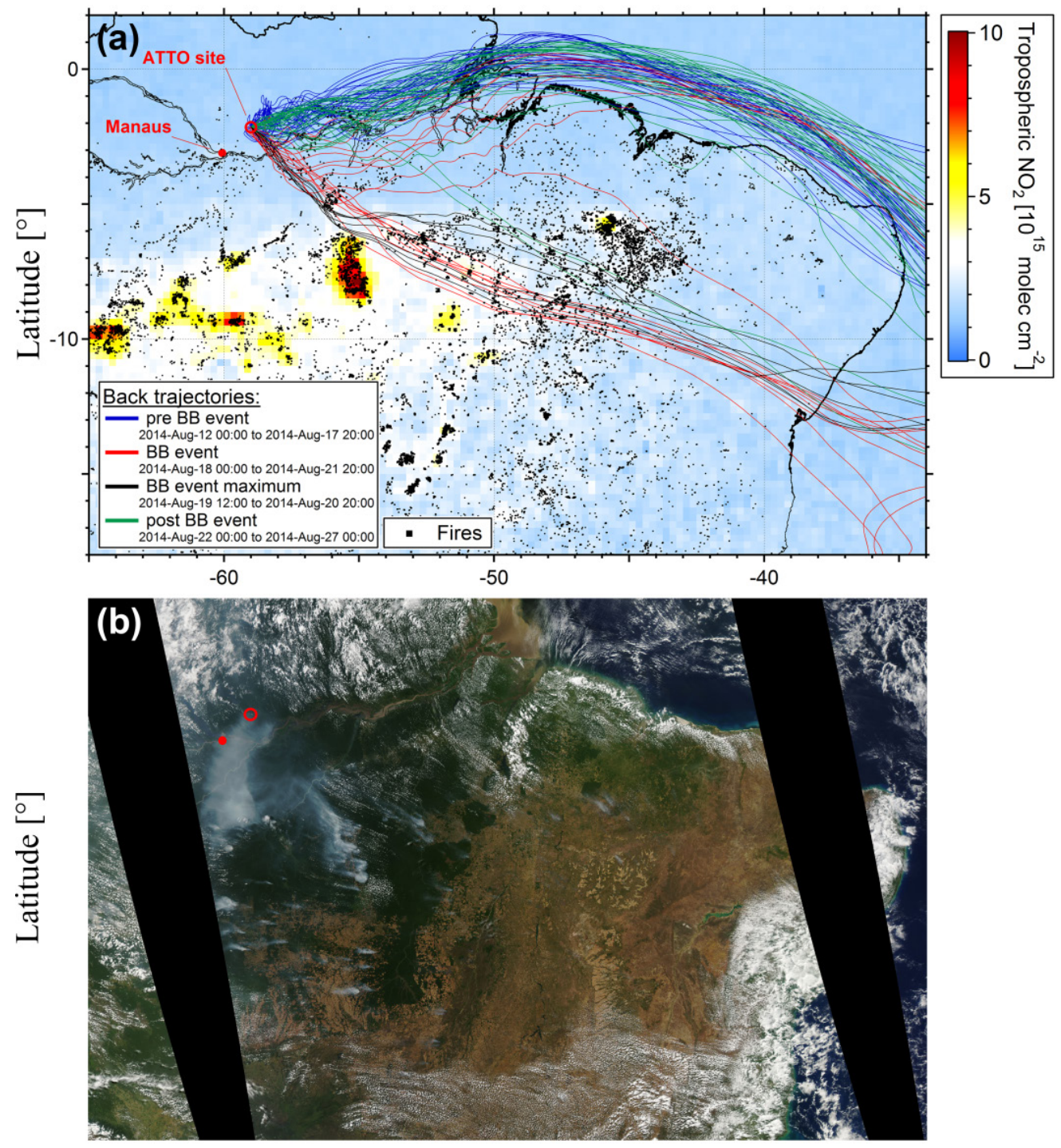

Longitude $\left[{ }^{\circ}\right]$

Figure S12. Composite maps illustrating origin of strong biomass burning (BB) plume that affected the ATTO site during $B B$ case study (17 to 23 Aug 2014). (a) Map combines BT ensembles for selected periods [HYSPLIT, NOAA-ARL, GDAS1, start height $200 \mathrm{~m}$, BTs started every 4 h, Draxler and Hess (1998)] with satellite products for active fire counts [MODIS active fire detection extracted from MCD14ML distributed by NASA FIRMS, Justice et al. (2011)] and $\mathrm{NO}_{2}$ atmospheric column (OMI/Aura $\mathrm{NO}_{2}$ Cloud-Screened Total and Tropospheric Column Daily L3 Global 0.25deg) during same period. BTs are color-coded for characteristic periods before, during, and after biomass burning event. BTs for pollution 'peak' at ATTO are color-coded as "BB event maximum”. Map indicates that the BTs' main track temporarily swings from 'coastal path' to 'inland path' and back. Inland BTs intersect areas with strong fire activity, as visible in fire counts as well as in $\mathrm{NO}_{2}$ map (i.e., $7^{\circ} \mathrm{S}, 55^{\circ}$ W). The most intense fires are located along the highway BR-163, which is known to be a hotspot of recent deforestation activities - for details, see C. Pöhlker et al. (2018). (b) MODIS corrected reflectance image (taken during Aqua overflight on 19 August 2014 1700UT) confirms that major fires at about $7^{\circ} \mathrm{S}$ and $55^{\circ} \mathrm{W}$ have emitted clearly visible smoke plume that travelled northwestwards and impacted the ATTO site during the $B B$ case study. 

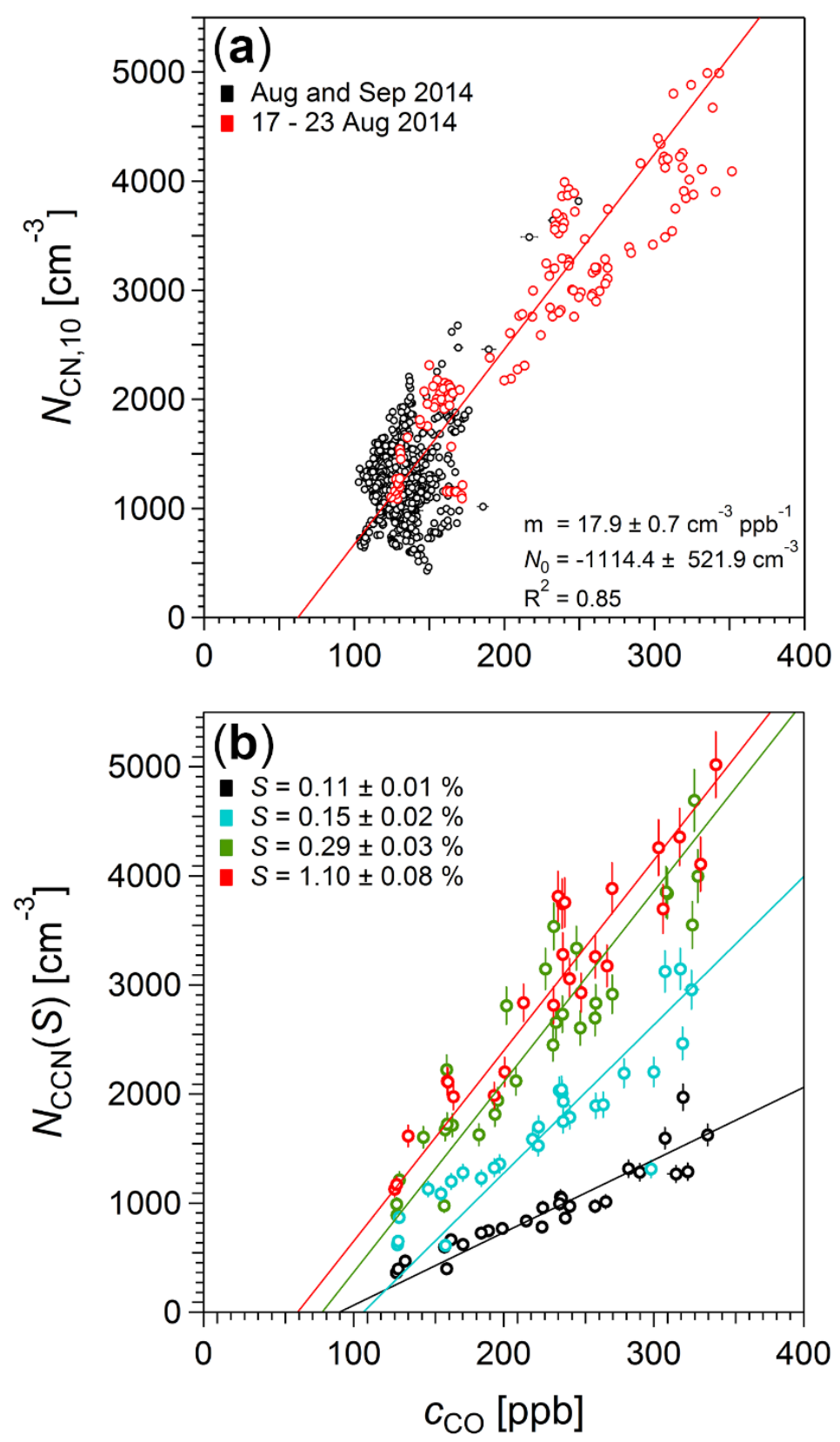

Figure S13. Scatter plots of total aerosol concentration, $N_{\mathrm{CN}, 10}$, and $\mathrm{CO}$ mixing ratio, $c_{\mathrm{CO}}$, as hourly average values with bivariate regression fit in (a) and scatter plot of CCN concentrations, $N_{\mathrm{CCN}}(S)$, and $\mathrm{CO}$ mixing ratio, $c_{\mathrm{CO}}$, for four selected $S$ with bivariate regression fit in (b). Data in both cases covers peak period of the biomass burning case study $B B$ (see Fig. 4). Error bars show standard errors. 

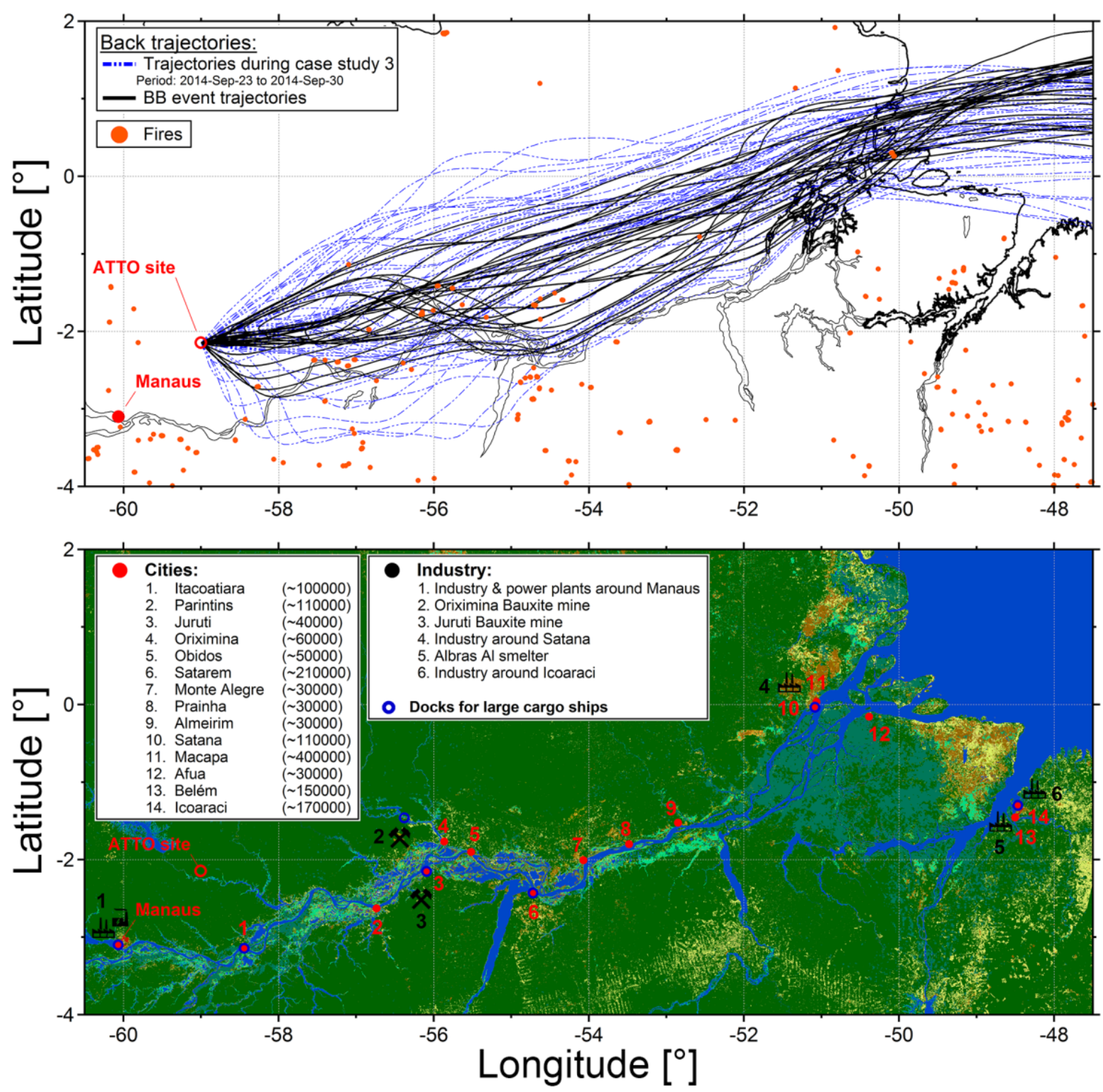

Figure S14. Composite maps illustrating conditions during $M P O L$ case study (23 to 30 September 2014). Upper map combines backward trajectories ensemble for selected periods (HYSPLIT, NOAAARL, GDAS1, start height $200 \mathrm{~m}$, trajectories started every 4 h) (Draxler and Hess, 1998) with satellite products for active fire counts (MODIS active fire detection extracted from MCD14ML distributed by NASA FIRMS) (Justice et al., 2011) during same period. Blue trajectories represent ensemble during entire MPOL period. Black trajectories highlight episodes with can be attributed to biomass burning plumes (24 Sep 2014 2200UT - 26 Sep 0800UT, 27 Sep 0000UT - 27 Sep 0600UT, 29 Sep 0000UT 29 Sep 1000UT). Main trajectory track follows westerly direction and passes several (smaller fires) along Amazon River. Lower map shows GlobCover 2009 data (Arino et al., 2008) and larger cities (population given in parenthesis) as well as larger industrial infrastructure along the Amazon River as further potential pollution sources. 
Table S1. Properties (position $x_{0}$, integral number concentration $N_{\mathrm{CN}}$, width $\sigma$ ) of Aitken and accumulation modes from double log-normal fits of the total particle size distribution for the $P R_{\mathrm{BC}}, P R_{\mathrm{CO}}$, and $P R_{\mathrm{BC}} \cup$ co cases as supplementary information to Table 2 . The errors represent the uncertainty of the fit parameters. The error in $S_{\text {cloud }}\left(D_{\mathrm{H}}, \kappa\right)$ is the experimentally derived error in $S$. For all double log-normal fits shown here, the fitted size range was limited to 50 - $350 \mathrm{~nm}$ since presence of particles in nucleation mode size range $(<50 \mathrm{~nm})$ interferes with fit of Aitken mode. All $N_{\mathrm{CN}}(D)$ and $\kappa\left(S, D_{\mathrm{a}}\right)$ size distributions specified here are plotted in Fig. S5. The following function has been used for the fitting of the experimentally obtained size distributions:

$$
f(x)=y_{0}+a_{1} * e^{-\left(\frac{\ln \left(\frac{x}{x_{1}}\right)}{\sigma_{1}}\right)^{2}}+a_{2} * e^{-\left(\frac{\ln \left(\frac{x}{x_{2}}\right)}{\sigma_{2}}\right)^{2}}
$$

Based on this function and the data in this table, the characteristic size distributions in this work can be implemented into modelling studies.

\begin{tabular}{|c|c|c|c|c|c|c|c|c|c|c|}
\hline Conditions & $\begin{array}{l}\text { Mode or } \\
\text { size range }\end{array}$ & $\begin{array}{c}N_{\mathrm{CN}} \\
{\left[\mathrm{cm}_{-3}\right]}\end{array}$ & $\kappa$ & $\begin{array}{c}y_{0} \\
{\left[\mathrm{~cm}_{-3}\right]}\end{array}$ & $\begin{array}{c}a_{\text {mode }} \\
{\left[\mathbf{c m}_{-3}\right]}\end{array}$ & $\begin{array}{l}x_{\text {mode }} \\
{[\mathrm{nm}]}\end{array}$ & $\sigma_{\text {mode }}$ & $R^{2}$ & $\begin{array}{c}D_{\mathbf{H}} \\
{[\mathrm{nm}]}\end{array}$ & $\begin{array}{c}S_{\text {cloud }}\left(D_{\mathrm{H}}, \kappa\right) \\
{[\%]}\end{array}$ \\
\hline $\begin{array}{l}\text { empirically pristine rain forest }(P R) \text { aerosol } \\
\left(P R_{\mathrm{BC}}\right)\end{array}$ & Aitken & $163 \pm 5$ & $0.13 \pm 0.01$ & $15 \pm 2$ & $416 \pm 2$ & $67 \pm 1$ & $0.47 \pm 0.01$ & 0.99 & $114 \pm 2$ & $0.23 \pm 0.01$ \\
\hline \multirow{2}{*}{$\begin{array}{l}\text { empirically pristine rain forest }(P R) \text { aerosol } \\
\left(P R_{\mathrm{CO}}\right)\end{array}$} & Aitken & $158 \pm 6$ & $0.13 \pm 0.02$ & \multirow{2}{*}{$22 \pm 3$} & $402 \pm 3$ & $67 \pm 1$ & $0.45 \pm 0.01$ & \multirow{2}{*}{0.99} & \multirow{2}{*}{$109 \pm 2$} & \multirow{2}{*}{$0.25 \pm 0.01$} \\
\hline & accumulation & $117 \pm 1$ & $0.19 \pm 0.01$ & & $268 \pm 4$ & $156 \pm 1$ & $0.48 \pm 0.01$ & & & \\
\hline \multirow{2}{*}{$\begin{array}{l}\text { empirically pristine rain forest }(P R) \text { aerosol } \\
\left(P R_{\mathrm{BC}} \cup \mathrm{CO}\right)\end{array}$} & Aitken & $157 \pm 5$ & $0.13 \pm 0.02$ & \multirow{2}{*}{$15 \pm 3$} & $417 \pm 2$ & $67 \pm 1$ & $0.45 \pm 0.01$ & \multirow{2}{*}{0.99} & \multirow{2}{*}{$111 \pm 2$} & \\
\hline & accumulation & $96 \pm 4$ & $0.18 \pm 0.01$ & & $234 \pm 3$ & $157 \pm 1$ & $0.47 \pm 0.01$ & & & \\
\hline \multirow{2}{*}{$\begin{array}{l}\text { empirically pristine rain forest }(P R) \text { aerosol } \\
\left(P R_{\mathrm{BC}} \cap \text { co filter }\right)\end{array}$} & Aitken & $162 \pm 4$ & $0.12 \pm 0.01$ & \multirow{2}{*}{$15 \pm 2$} & $423 \pm 2$ & $69 \pm 2$ & $0.46 \pm 0.01$ & \multirow{2}{*}{0.99} & \multirow{2}{*}{$103 \pm 2$} & \multirow{2}{*}{$0.29 \pm 0.01$} \\
\hline & accumulation & $86 \pm 8$ & $0.18 \pm 0.01$ & & $217 \pm 3$ & $157 \pm 1$ & $0.44 \pm 0.01$ & & & \\
\hline \multirow{2}{*}{ long-range transport $(L R T)$ aerosol } & Aitken & $125 \pm 12$ & $0.18 \pm 0.02$ & \multirow{2}{*}{$13 \pm 2$} & $250 \pm 9$ & $79 \pm 3$ & $0.60 \pm 0.03$ & \multirow{2}{*}{0.99} & \multirow{2}{*}{$118 \pm 2$} & \multirow{2}{*}{$0.15 \pm 0.01$} \\
\hline & accumulation & $313 \pm 11$ & $0.35 \pm 0.04$ & & $770 \pm 14$ & $179 \pm 2$ & $0.52 \pm 0.01$ & & & \\
\hline \multirow{2}{*}{ biomass burning $(B B)$ aerosol } & Aitken & $140 \pm 29$ & $0.14 \pm 0.01$ & \multirow{2}{*}{$40 \pm 23$} & $688 \pm 77$ & $70 \pm 1$ & $0.20^{\mathrm{b}}$ & \multirow{2}{*}{0.99} & \multirow{2}{*}{--} & \multirow{2}{*}{--} \\
\hline & accumulation & $3439 \pm 39$ & $0.17 \pm 0.02$ & & $7680 \pm 49$ & $167 \pm 1$ & $0.58 \pm 0.01$ & & & \\
\hline \multirow{4}{*}{$\begin{array}{l}\text { mixed pollution }(M P O L) \\
\text { aerosol }\end{array}$} & $<100 \mathrm{~nm}$ & \multirow{2}{*}{$1272 \pm 27$} & $0.14 \pm 0.01$ & \multirow{2}{*}{$4 \pm 7$} & \multirow{2}{*}{$1982 \pm 10$} & \multirow{2}{*}{$135 \pm 5$} & $085+001$ & 00 & 年 & 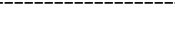 \\
\hline & $>100 \mathrm{~nm}$ & & $0.22 \pm 0.03$ & & & & $0.85 \pm 0.01$ & 0.99 & -- & -- \\
\hline & $<150 \mathrm{~nm}$ & $2764+84$ & $0.10 \pm 0.01$ & & $4418 \pm 30$ & $112+1$ & 081 & 000 & 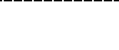 & 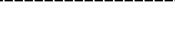 \\
\hline & $>150 \mathrm{~nm}$ & $2 / 04 \pm 84$ & $0.20 \pm 0.04$ & 18 & & $113 \pm 1$ & $0.81 \pm 0.01$ & 0.99 & -- & -- \\
\hline
\end{tabular}


Table S2. Aerosol chemical composition from ACSM measurements at ATTO for $P R$ filters as supplementary information to Table 3 . ACSM data was available for time period from 01 Aug 2014 to 30 Sep 2016 and the averaged values are shown here as mean \pm std. The shown ACSM $3 \sigma$ detection limits for 30 min averaging time were obtained from $\mathrm{Ng}$ et al. (2011). Note that $M_{\mathrm{NH} 4}$ ranged below the instruments detection limit in all $P R$ cases, which makes the corresponding results unreliable. The predicted average aerosol hygroscopicity parameter, $\kappa_{\mathrm{p}}$, was calculated according to the part 1 study (M. Pöhlker et al., 2016) and is shown as mean \pm se. The $\kappa(0.10 \%)$ results are shown with the experimentally derived error.

\begin{tabular}{|c|c|c|c|c|c|c|c|c|c|}
\hline \multirow{2}{*}{ Time period } & \multicolumn{6}{|c|}{ Mass concentrations $M_{\text {species }}\left[\mu \mathrm{g} \mathrm{m}^{-3}\right] \quad \& \quad$ (Mass fraction [\%]) } & \multicolumn{2}{|l|}{$\mathrm{OA} / \mathrm{SO}_{4}^{2}$} & \multirow{2}{*}{$\kappa(0.10 \%)$} \\
\hline & $\mathbf{O A}$ & $\mathrm{NO}_{3}^{-}$ & $\mathrm{NH}_{4}{ }^{+}$ & $\mathrm{SO}_{4}{ }^{2-}$ & $\mathbf{C l}$ & $\mathbf{B C}_{\mathrm{e}}$ & - & $\boldsymbol{n}_{\mathrm{p}}$ & \\
\hline $\begin{array}{l}\text { empirically pristine rain forest }(P R) \\
\text { aerosol }\left(P R_{\mathrm{BC}}\right)\end{array}$ & $\begin{array}{c}0.64 \pm 0.01 \\
(90) *\end{array}$ & $\begin{array}{c}0.03 \pm 0.03 \\
(4) *\end{array}$ & $\begin{array}{l}0.18 \pm 0.01^{\mathrm{a}} \\
(-)^{*}\end{array}$ & $\begin{array}{l}0.04 \pm 0.01 \\
(6)^{*}\end{array}$ & $\begin{array}{c}<(0.01 \pm 0.01) \\
(--)^{*}\end{array}$ & $\begin{array}{c}<(0.01 \pm 0.01) \\
(--)^{*}\end{array}$ & $\sim 46$ & $0.16 \pm 0.01 *$ & $0.19 \pm 0.05$ \\
\hline $\begin{array}{l}\text { empirically pristine rain forest }(P R) \\
\text { aerosol }\left(P R_{\mathrm{CO}}\right)\end{array}$ & $\begin{array}{c}0.77 \pm 0.01 \\
(82)^{*}\end{array}$ & $\begin{array}{c}0.04 \pm 0.01 \\
(4)^{*}\end{array}$ & $\begin{array}{c}0.17 \pm 0.01^{\mathrm{a}} \\
(--)^{*}\end{array}$ & $\begin{array}{c}0.09 \pm 0.01 \\
(9) *\end{array}$ & $\begin{array}{l}0.01 \pm 0.01 \\
(1)^{*}\end{array}$ & $\begin{array}{c}0.03 \pm 0.01 \\
(3) *\end{array}$ & $\sim 30$ & $0.19 \pm 0.01 *$ & $0.19 \pm 0.04$ \\
\hline $\begin{array}{l}\text { empirically pristine rain forest }(P R) \\
\text { aerosol }\left(P R_{\mathrm{BC}} \cup \mathrm{CO}\right)\end{array}$ & $\begin{array}{c}0.75 \pm 0.01 \\
(83) *\end{array}$ & $\begin{array}{l}0.04 \pm 0.01 \\
(4)^{*}\end{array}$ & $\begin{array}{c}0.17 \pm 0.01^{\mathrm{a}} \\
(--)^{*}\end{array}$ & $\begin{array}{c}0.08 \pm 0.01 \\
(9)^{*}\end{array}$ & $\begin{array}{l}0.01 \pm 0.01 \\
(1)^{*}\end{array}$ & $\begin{array}{c}0.02 \pm 0.01 \\
(2)^{*}\end{array}$ & $\sim 30$ & $0.18 \pm 0.03 *$ & $0.19 \pm 0.04$ \\
\hline Detection limits of ACSM \& MAAP & 0.15 & 0.01 & 0.28 & 0.02 & 0.01 & 0.01 & -- & -- & -- \\
\hline
\end{tabular}

${ }^{a}$ Here, measured $M_{\mathrm{NH} 4}$ ranged below the ACSM detection limit and the shown values are questionable. Therefore, mass factions and $\kappa_{\mathrm{p}}$ were calculated by omitting $M_{\mathrm{NH} 4}$ as outlined in Sect. 2.1. The corresponding results are marked by *. 
Table S3. Error function (erf) fit parameters describing CCN efficiency spectra $N_{\mathrm{CCN}}(S) / N_{\mathrm{CN}, 10}$ vs. $S$ as model input data representing $P R$ filters as supplementary information to Table 4. A reference concentration of $N_{\mathrm{CN}, 10}$ has been used in all cases. $N_{\mathrm{CN}}$ is shown as mean \pm se. The errors in $S_{\mathrm{mode}}$ and $w_{\mathrm{mode}}$ represent the uncertainty of the fit parameters (see Sect. 2.2). All CCN efficiency spectra specified here are plotted in Fig. S8.

\begin{tabular}{|c|c|c|c|c|c|c|c|}
\hline Time period & $N_{\mathrm{CN}}\left[\mathrm{cm}^{-3}\right]$ & erf fit & mode & $a_{\text {mode }}$ & $S_{\text {mode }}[\%]$ & $w_{\text {mode }}$ & $\mathbf{R}^{2}$ \\
\hline \multirow{3}{*}{$\begin{array}{l}\text { empirically pristine rain forest }(P R) \\
\text { aerosol }\left(P R_{\mathrm{BC}}\right)\end{array}$} & \multirow{3}{*}{$255 \pm 2$} & single & 1 & 1 & $0.47 \pm 0.01$ & $1.69 \pm 0.06$ & 0.99 \\
\hline & & \multirow{2}{*}{ double } & 1 & 1 & $0.11 \pm 0.01$ & $0.47 \pm 0.26$ & \multirow{2}{*}{0.99} \\
\hline & & & 2 & $0.19 \pm 0.06$ & $0.65 \pm 0.06$ & $1.18 \pm 0.14$ & \\
\hline \multirow{3}{*}{$\begin{array}{l}\text { empirically pristine rain forest }(P R) \\
\text { aerosol }\left(P R_{\mathrm{CO}}\right)\end{array}$} & \multirow{3}{*}{$292 \pm 2$} & single & 1 & 1 & $0.38 \pm 0.01$ & $1.79 \pm 0.07$ & 0.99 \\
\hline & & \multirow{2}{*}{ double } & 1 & 1 & $0.11 \pm 0.01$ & $0.52 \pm 0.22$ & \multirow{2}{*}{0.99} \\
\hline & & & 2 & $0.28 \pm 0.07$ & $0.62 \pm 0.08$ & $1.17 \pm 0.18$ & \\
\hline \multirow{3}{*}{$\begin{array}{l}\text { empirically pristine rain forest }(P R) \\
\text { aerosol }\left(P R_{\mathrm{BC}} \cup \mathrm{CO}\right)\end{array}$} & \multirow{3}{*}{$276 \pm 2$} & single & 1 & 1 & $0.41 \pm 0.01$ & $1.71 \pm 0.06$ & 0.99 \\
\hline & & \multirow{2}{*}{ double } & 1 & 1 & $0.11 \pm 0.01$ & $0.50 \pm 0.27$ & \multirow{2}{*}{0.99} \\
\hline & & & 2 & $0.22 \pm 0.07$ & $0.60 \pm 0.07$ & $1.21 \pm 0.16$ & \\
\hline
\end{tabular}


Table S4. Excess $N_{\mathrm{CCN}}(S)$ to excess $c_{\mathrm{CO}}$ ratios, $\Delta N_{\mathrm{CCN}}(S) / \Delta c_{\mathrm{CO}}$, for the individual $S$ levels during peak period of the biomass burning event in case study BB (17 - 23 August 2014, see Table 1). Ratios $\Delta N_{\mathrm{CCN}}(S) / \Delta c_{\mathrm{CO}}$ were obtained from bivariate regression fits (see Fig. S13b).

\begin{tabular}{cccc}
\hline $\boldsymbol{S}$ & $\begin{array}{c}\Delta \boldsymbol{N}_{\mathbf{C C N}}(\boldsymbol{S}) / \Delta \mathbf{C O} \\
{[\mathbf{~}]}\end{array}$ & $\boldsymbol{N}$ & $\boldsymbol{R}^{2}$ \\
\hline $\left.\mathbf{c m}^{-3} \mathbf{p p b}^{-1}\right]$ & {$\left[\mathbf{c m}^{-3}\right]$} & \\
\hline $0.11 \pm 0.01$ & $6.7 \pm 0.5$ & $-603 \pm 125$ & 0.86 \\
$0.15 \pm 0.02$ & $13.6 \pm 1.4$ & $-1447 \pm 354$ & 0.68 \\
$0.24 \pm 0.03$ & $14.3 \pm 0.8$ & $-1128 \pm 208$ & 0.90 \\
$0.29 \pm 0.03$ & $16.8 \pm 1.0$ & $-1460 \pm 261$ & 0.86 \\
$0.47 \pm 0.04$ & $17.4 \pm 1.3$ & $-1378 \pm 296$ & 0.83 \\
$0.61 \pm 0.06$ & $20.1 \pm 1.7$ & $-1675 \pm 425$ & 0.84 \\
$0.74 \pm 0.08$ & $17.9 \pm 1.3$ & $-1206 \pm 332$ & 0.88 \\
$0.92 \pm 0.11$ & $16.5 \pm 1.3$ & $-933 \pm 329$ & 0.88 \\
$1.10 \pm 0.08$ & $18.1 \pm 1.4$ & $-1265 \pm 355$ & 0.85 \\
\hline
\end{tabular}




\section{References}

Arino, O., Bicheron, P., Achard, F., Latham, J., Witt, R., and Weber, J.-L.: GLOBCOVER The most detailed portrait of Earth, Esa Bulletin-European Space Agency, 24-31, 2008.

de Carvalho, W. D., and Mustin, K.: The highly threatened and little known Amazonian savannahs, Nature Ecology \& Evolution, 1, 0100, 10.1038/s41559-017-0100 https://www.nature.com/articles/s41559-0170100\#supplementary-information, 2017.

Draxler, R. R., and Hess, G. D.: An overview of the HYSPLIT_4 modelling system for trajectories, dispersion and deposition, Australian Meteorological Magazine, 47, 295-308, 1998.

Gunthe, S. S., King, S. M., Rose, D., Chen, Q., Roldin, P., Farmer, D. K., Jimenez, J. L., Artaxo, P., Andreae, M. O., Martin, S. T., and Poschl, U.: Cloud condensation nuclei in pristine tropical rainforest air of Amazonia: sizeresolved measurements and modeling of atmospheric aerosol composition and CCN activity, Atmospheric Chemistry and Physics, 9, 7551-7575, 2009.

Justice, C., Giglio, L., Roy, D., Boschetti, L., Csiszar, I., Davies, D., Korontzi, S., Schroeder, W., O’Neal, K., and Morisette, J.: MODIS-Derived Global Fire Products, in: Land Remote Sensing and Global Environmental Change, edited by: Ramachandran, B., Justice, C. O., and Abrams, M. J., Remote Sensing and Digital Image Processing, Springer New York, 661-679, 2011.

Laskin, A., Iedema, M. J., Ichkovich, A., Graber, E. R., Taraniuk, I., and Rudich, Y.: Direct observation of completely processed calcium carbonate dust particles, Faraday Discuss., 130, 453-468, 10.1039/b417366j, 2005.

Laskin, A., Moffet, R. C., Gilles, M. K., Fast, J. D., Zaveri, R. A., Wang, B., Nigge, P., and Shutthanandan, J.: Tropospheric chemistry of internally mixed sea salt and organic particles: Surprising reactivity of $\mathrm{NaCl}$ with weak organic acids, Journal of Geophysical Research-Atmospheres, 117, 10.1029/2012jd017743, 2012.

Moran-Zuloaga, D., Ditas, F., Walter, D., Saturno, J., Brito, J., Carbone, S., Chi, X., Hrabě de Angelis, I., Baars, H., Godoi, R. H. M., Heese, B., Holanda, B. A., Lavrič, J. V., Martin, S. T., Ming, J., Pöhlker, M., Ruckteschler, N., Su, H., Wang, Y., Wang, Q., Wang, Z., Weber, B., Wolff, S., Artaxo, P., Pöschl, U., Andreae, M. O., and Pöhlker, C.: Long-term study on coarse mode aerosols in the Amazon rain forest with the frequent intrusion of Saharan dust plumes, Atmos. Chem. Phys. Discuss., 2017, 1-52, 10.5194/acp-2017-1043, 2017.

Olson, D. M., Dinerstein, E., Wikramanayake, E. D., Burgess, N. D., Powell, G. V. N., Underwood, E. C., D'amico, J. A., Itoua, I., Strand, H. E., Morrison, J. C., Loucks, C. J., Allnutt, T. F., Ricketts, T. H., Kura, Y., Lamoreux, J. F., Wettengel, W. W., Hedao, P., and Kassem, K. R.: Terrestrial Ecoregions of the World: A New Map of Life on Earth, Bioscience, 51, 933-938, 10.1641/0006-3568(2001)051[0933:teotwa]2.0.co;2, 2001.

Pöhlker, M. L., Pöhlker, C., Klimach, T., Hrabe de Angelis, I., Barbosa, H. M. J., Brito, J., Carbone, S., Cheng, Y., Chi, X., Ditas, F., Ditz, R., Gunthe, S. S., Kesselmeier, J., Könemann, T., Lavrič, J. V., Martin, S. T., MoranZuloaga, D., Rose, D., Saturno, J., Su, H., Thalman, R., Walter, D., Wang, J., Wolff, S., Artaxo, P., Andreae, M. O., and Pöschl, U.: Long-term observations of cloud condensation nuclei in the Amazon rain forest - Part 1: Aerosol size distribution, hygroscopicity, and new model parameterizations for $\mathrm{CCN}$ prediction, Atmos. Chem. Phys., 16, 15709-15740, 10.5194/acp-2016-519, 2016.

Pöhlker, C., Walter, D., Paulsen, H., Könemann, T., Rodríguez-Caballero, E., Moran-Zuloaga, D., Brito, J., Carbone, S., Degrendele, C., Després, V. R., Ditas, F., Holanda, B. A., Kaiser, J. W., Lammel, G., Lavrič, J. V., Jing, M., Pickersgill, D., Pöhlker, M. L., Praß, M., Ruckteschler, N., Saturno, J., Sörgel, M., Wang, Q., Weber, B., Wolff, S., Artaxo, P., Pöschl, U., and Andreae, M. O.: Land cover and its transformation in the backward trajectory footprint of the Amazon Tall Tower Observatory, Atmos. Chem. Phys. Diss, submitted, 2018.

Roberts, G. C., Nenes, A., Seinfeld, J. H., and Andreae, M. O.: Impact of biomass burning on cloud properties in the Amazon Basin, Journal of Geophysical Research-Atmospheres, 108, 10.1029/2001jd000985, 2003. 